\title{
Making the Case for Political Engagement by Public Health Professionals
}

\author{
LAURIE FRIEDMAN, PHD ${ }^{1}$; PATRICIA DORMER ${ }^{1}$; DAVID B. SARWER, PHD²,3 \\ ${ }^{1}$ School of Social Work, College of Public Health, Temple University \\ 2 Department of Social and Behavioral Sciences, College of Public Health, Temple University \\ ${ }^{3}$ Center for Obesity Research and Education, College of Public Health, Temple University
}

Correspondence: lauriefr@temple.edu (Laurie Friedman)

\section{Introduction}

During the course of our practice, clinicians, social workers and other public health professionals witness the intricate connections between policies and the health of the individuals and communities we work with. Temple's College of Public Health recognizes service as key components of its mission to "embrace public health as a catalyst for individual and community change and well-being". ${ }^{1}$ Political engagement by $\mathrm{CPH}$ faculty, staff and students at the local, state and federal levels affords opportunities to share our research and practice experiences to advocate for changes that address public concerns, and to elect representatives that share our values. Furthermore, the disparate effects of COVID-19 illustrate existing social inequities and the usefulness of the social determinants of health framework in understanding and addressing these inequities and remind us of the importance of political engagement as a component of practice within each of our respective disciplines' ethical codes. A belief that underlies the 12 Principles of the Ethical Practice of Public Health is that "each person in a community should have an opportunity to contribute to public discourse."'2 Clinicians, social workers and other public health professionals should exemplify both this principle and their respective professional ethical codes. Examples of discipline specific ethical principles are summarized in Table 1.

Table 1. Public Health Professionals Ethical Principals and Code of Ethics

Athletic Trainers: Athletic trainers are obligated to place the well-being and long-term well-being of their patient above other groups and their own self-interest, to provide competent care in all decisions, and advocate for the best medical interest and safety of their patient at all times as delineated by professional statements and best practices. The full code of ethics can be accessed at https://www.nata.org/membership/about-membership/member-resources/code-of-ethics Kinesiology: Members of the AKA share the profession's responsibility to society in matters relating to the well-being of the community. The full code of ethics can be accessed at https://www.albertakinesiology.ca/cpages/code-of-ethics.

Nursing: Nursing professionals promise to provide and advocate for safe, quality care for all patients and communities. The full code of ethics can be accessed at https://www.nursingworld.org/practice-policy/nursing-excellence/ethics.

Occupational Therapy: Occupational therapists shall advocate for changes to systems and policies that are discriminatory or unfairly limit or prevent access to occupational therapy services. The full code of ethics can be accessed at https://ajot.aota.org/article.aspx?articleid $=2442685$. 


\begin{tabular}{l} 
Physical Therapy: Physical therapists shall advocate to reduce health disparities and health care inequities, improve \\
access to health care services, and address the health, wellness, and preventive health care needs of people. The full code \\
of ethics can be accessed at https://www.apta.org/siteassets/pdfs/policies/codeofethicshods06-20-28-25.pdf. \\
\hline Speech Language Hearing: Members of ASHA share the profession's responsibility to persons served professionally \\
and to research participants, both human and animal, to the public and for one's professional competence and for \\
professional relationships. The full code of ethics can be accessed at https://www.asha.org/Code-of-Ethics/. \\
\hline $\begin{array}{l}\text { Social Work: Social Workers shall engage in social and political action and facilitate informed participation by the public } \\
\text { in shaping social policies and institutions. The full code of ethics can be accessed at } \\
\text { https://www.socialworkers.org/About/Ethics/Code-of-Ethics/Code-of-Ethics-English. }\end{array}$
\end{tabular}

\section{Defining Political Engagement}

Civic engagement consists of a series of private and public actions along a continuum, ranging from taking out a neighbor's trash to running for elected office. ${ }^{3}$ Whether in the community or political domain, these actions seek to impact our collective well-being and influence how public decisions are made and how resources are allocated. ${ }^{4}$ The political domain of civic engagement involves actions geared towards influencing decisions made by one or more branches of local, state and federal governments, and influencing the elected officials who make these decisions. ${ }^{4}$ These actions include, but are not limited to: following the news, voting, donating money to a campaign, volunteering/working for a campaign, following what elected officials do/how they vote (i.e. issues related to scope of practice and reimbursement for our services), working for an advocacy group, contacting elected officials, attending protests and running for elected office. ${ }^{5}$

\section{Benefits of Political Engagement}

Within the social determinants of health framework, the social and community context domain notes the relationship between civic participation and health and quality of life outcomes. For example, increased voter participation is associated with better mental and physical health outcomes. ${ }^{6}$ Conversely, a 2016 Kansas report found a correlation between low levels of political engagement and poor physical health. ${ }^{7}$ Martin and Claibourn ${ }^{8}$ found that increased political engagement by communities, specifically related to voter turnout, was correlated with increased policy responsiveness by these communities' elected representatives. Sanders ${ }^{9}$ research demonstrated political participation is one resource that may alleviate negative mental health concerns associated with vulnerable populations. The Robert Woods Johnson Foundation notes that communities with high levels of civic engagement are empowered communities who hold elected officials accountable for effective and efficient decision-making that provides meaningful and sustainable public health policy. Additionally, the process of voting and continued civic engagement builds knowledge and skills tied to overall individual and community health and well-being. ${ }^{10}$

\section{Opportunities for Political Engagement}

\section{November 2020 Elections}

Despite the importance of elections in affecting legislation that impacts the health of individual and communities, political engagement is typically low. For example, voter turnout in 2016, as measured by an estimate of the persons eligible to vote regardless of voter registration status in an election, was $59.2 \%$ for the presidential ballot. In the 2018 midterm elections, voter turnout was 50\%. In Pennsylvania, despite an approximately thirty percent increase in voter turnout for municipal elections in 2019, turnout was 
below 50\%.11 In Philadelphia, $28 \%$ of people voted. Voter turnout varies by a number of demographic variables. Older, wealthier Americans with higher levels of education tend to vote at higher rates. NonHispanic Whites and Blacks tend to vote more often than Hispanics and other racial/ethnic groups. ${ }^{12}$

Election laws vary by state, making it important to be aware of laws related to voter eligibility and key dates prior to the November 3rd general election. Vote.org and votes.temple.edu provide ample information on how to register (with deadlines for each state) and where to vote/vote by mail, voting rights, first time voter checklists and how to make a plan to vote on the day. College students can choose to register to vote at their college or permanent address. Those of us working at nonprofits can legally share this information with those we work with, empowering them to participate in the process, too. ${ }^{13}$ Please see the table at the end of this article for information specific to our tri-county region.

As happens every four years, much attention has been focused on this year's presidential election. Attention dissipates, however, as we move down ballot from President and other federal offices to state and municipal elections. This year, 35 US Senators are running for re-election and each of the 435 members of the US House of Representatives is up for reelection. The outcomes of these Congressional elections will directly affect the legislation brought forth from Congress as well as confirmation of future Supreme Court justices. In Pennsylvania, 25 state senators (including MPH graduate Amanda Cappalletti) are on the ballot and every PA state representative is up for reelection, as they each serve 2-year terms. This interactive US election map site provides information on the specific offices up for election. ${ }^{14}$ Please take time to research local, state and federal candidates and issues. You can check your state guide to find further information. ${ }^{15}$

\section{Opportunities Beyond 2020}

\section{CPH Opportunities}

$\mathrm{CPH}$ provides a multitude of opportunities for political engagement and interdisciplinary collaboration. For example, the CPH's COVID-19 Beyond Biology series in Spring 2020 provided a forum for experts to discuss public health issues amplified by the pandemic and included actions related to policy changes to address these issues. Social Justice, Public Health, and the 2020 Election were the focus of the September 18th CPH Dean's Seminar with representatives from the League of Women Voters as well as PA local and state officials (including Dr. Monica Taylor, who holds a PhD in Kinesiology). Through a Council for Social Work Education (CSWE) grant, CPH will host an event to build on the work of Dr. Martin Luther King, Jr. in January of 2021. Faculty, staff, students and community members will be invited for discussions that focus on policy-level interventions that address the effects of the intersection of race and poverty. The grant also funds development of a webpage focused on these issues with corresponding resources and information. CPH faculty can, and do, cultivate knowledge and skills within their courses on how to be politically active and advocate for public health policies (and funding) that will meaningfully and sustainably improve the health and well-being of clients and communities. $\mathrm{CPH}$ students intern in executive and legislative offices as well as advocacy organizations, providing opportunities to apply the concepts, techniques, and theories learned in the classroom. Additionally, CPH faculty, staff and students can share their research and practice related to public health equity and justice at conferences, workshops, and meetings with elected officials. In partnership with regional social work departments, the School of Social Work will co-host a Campaign School in Spring 2021. Lead by the Humphreys Institute for Political Social Work, Campaign School teaches social workers how to run for office, work in government leadership positions, advocate for social change, and understand their own 
political power. Many of our alumni work in political offices, such as Dr. Angali Chainani (MSW/MPH from Temple), who serves as Director of Policy in the Philadelphia Mayor's Office.

\section{Discipline Specific Opportunities}

Political action committees (PACs) are organizations formed that support specific ideological values and beliefs and who raise money to support or defeat specific candidates or issues. An example of a PAC aligned to broad public health issues such as health care for all is America's Progressive PAC. PACs aligned to individual public health professions exist including PACE (Political Action for Candidate Election within the NASW), ASHA-PAC (the PAC of the American Speech-Language-Hearing Association), and ANA-PAC (the American Nurses Association's Political Action Committee). Engagement with professionally-aligned PACS provide public health professionals a venue through which to achieve their ethical commitment to the individual clients and communities they serve.

\section{Preparing for 2021's Elections}

Next year there are local (mayor, city and county councils, school boards and election boards) elections and/or ballot issues that impact our lives and the lives of those we work with. Election board positions are non-partisan and consist of the individuals who staff voting precincts: judges of elections, majority and minority inspectors and clerks. While individuals have volunteered to fill in gaps this fall, we need to think about how we can ensure they remain filled in non-presidential election years. Think about subscribing to your local newspaper, following local issues on social media, attending municipal and school board meetings and/or running to serve in one of these positions. Follow the votes of elected officials using free apps such as Countable.

\section{Conclusion}

Elections are an opportunity for us to assess the job performance of those entrusted to make decisions that promote the public good, support new candidates, and/or choose to serve in public office ourselves. As public health workers committed to advancing research, scholarship and practice, we make a difference in the daily lives of the individuals we serve. We can also engage politically at the local, state and federal levels to work with elected officials and leverage our collective knowledge, values and skills to promote the health of individuals and communities. Voting is an essential component of civic engagement, providing the foundation of a continuum of opportunities for us to engage politically. In addition to voting this November, we urge everyone to think about what we can do to address public health issues through continued political civic engagement and activism throughout the year.

Table 2. Voter Registration Deadlines in Pennsylvania, New Jersey and Delaware

\begin{tabular}{|l|l|}
\hline Pennsylvania & $\begin{array}{l}\text { October } 19 \text { is the last day to register to vote for the November election. } \\
\text { October } 27 \text { is the last day to request an absentee ballot or mail-in ballot to vote }\end{array}$ \\
\hline New Jersey & $\begin{array}{l}\text { October } 13 \text { is the last day to register to vote for the November election. } \\
\text { November } 2 \text { is the last day to request an absentee ballot or mail-in ballot. }\end{array}$ \\
\hline Delaware & $\begin{array}{l}\text { October } 10 \text { is the last day to register to vote for the November election. } \\
\text { October } 30 \text { is the last day to request an absentee ballot or mail-in ballot. }\end{array}$ \\
\hline $\begin{array}{l}\text { If you are voting in person, confirm your polling location as it may have changed due to the pandemic. Polling places } \\
\text { and other resources, including signing up to work the polls, can be found at the Temple Votes site } \\
\text { here: https://deanofstudents.temple.edu/temple-votes. }\end{array}$ \\
\hline
\end{tabular}




\section{Disclosures and Conflicts of Interest}

The authors disclose there is no conflict of interest.

\section{References}

1. College of Public Health (CPH) Temple University website (no date [n.d.]). Retrieved from https://cph.temple.edu/about.

2. American Public Health Association (APHA). 2002. Retrieved from https://www.apha.org//media/files/pdf/membergroups/ethics/ethics_brochure.ashx

3. Adler RP, Goggin J. What Do We Mean By "Civic Engagement"? Journal of Transformative Education. 2005;3(3):236-253.

4. Sherraden MS, Lough B, Mcbride AM. Effects of international volunteering and service: Individual and institutional predictors. Voluntas. 2008;19(4):395-421.

5. Rome, S.H., and Hoechstetter, S. Social work and civic engagement: the political participation of professional social workers. 2010. Retrieved from https://www.researchgate.net/publication/290575989_Social_work_and_civic_engagement_The_ political_participation_of_professional_social_workers.

6. Ballard, P. J., Hoyt, L. T., and Pachucki, M. C. Impacts of Adolescent and Young Adult Civic Engagement on Health and Socioeconomic Status in Adulthood. Child Development. 2019. 90(4), $1138-1154$.

7. Kansas Health Foundation. 2016 Kansas Civic Health Index. 2016. Retrieve from https://kansashealth.org/resources/kansas-civil-health-index/

8. Martin, P., and Claibourn, M. Citizen Participation and Congressional Responsiveness: New Evidence that Participation Matters. Legislative Studies Quarterly. 2013. 38(1), 59-81.

9. Sanders, L. APSA Awards Presented at the 2014 Annual Meeting. PS: Political Science \& Politics. 2014;47(4):924-931.

10. Robert Wood Johnson Foundation. (no date [n.d.]). Retrieved from https://www.rwjf.org/en/cultureofhealth/taking-action/making-health-a-shared-value/civic-

engagement.html

11. Lai, S., and Seidman, A. Voter turnout surged across the Philadelphia region amid a 'highly polarized electorate'. Philadelphia Inquirer. 2019. Retrieved from https://www.inquirer.com/news/voterturnout-philadelphia-pennsylvania-elections-2019-20191108.html

12. United States Election Project. 2020. Retrieved from http://www.electproject.org.

13. Nonprofit VOTE. 2020. Retrieved from https://www.nonprofitvote.org/ 
14. Ballotpedia. $2020 . \quad$ Retrieved from https://ballotpedia.org/Elections\#2020_election_coverage_by_office

15. Campus Vote Project. 2020. Retrieved from https://www.campusvoteproject.org/state-studentvoting-guides

\section{Statement of Contributions}

All authors contributed to the conceptualization, writing, reviewing and editing of the article.

\section{ORCID IDs}

David B. Sarwer: https://orcid.org/0000-0003-1033-5528 